\title{
Keep out! No entry! Exploring the Soviet military landscape of the coast of Estonia
}

\author{
Ann-Leena Miller ${ }^{1}$ \\ ${ }^{1}$ Estonian University of Life Sciences, Chair of Landscape Architecture, Tartu, Estonia
}

\begin{abstract}
During the Soviet occupation of 1945-1991, Estonia became a Soviet Republic and was cut off from open contact with the Western world. The Estonian coastline was now the outer border of the Soviet Union and part of the Iron Curtain. On the coast of the Baltic Sea this was less visible than in some places (e.g. the Berlin wall), but the military control was no less restrictive. The coastal areas were under military control and accessible only with special permits - so often the inhabitants had to leave and their homes were taken over by the Soviet military or abandoned. Military installations also marked the Soviet security zone. There was a massive construction programme of artillery defensive positions along the coastline. As the last Soviet troops left Estonia in 1994, the Soviet military installations were left to the Estonian Republic. Most were stripped of anything useful and abandoned. Many of these objects or complexes are still visible in the landscape but most are forgotten and ruined. They are not yet seen as a part of Estonian heritage and are fast disappearing. A study of a section of the NE coast of Estonia has identified a military landscape along with the former closed city of Sillamäe (where uranium was refined). Mapping of the defence structures, assessment of their condition and their visible presence reveals a distinctive military landscape alongside collectivised agriculture, where residential quarters, roads and communications formed a unique complex. Interviews with local residents reveal how the zone and the restrictions were ever present in their lives and generally they are not interested in them or their preservation; younger interviewees with no memory view the remains as curiosities; there is the beginning of interest in them as part of a "dissonant heritage".
\end{abstract}

\section{Introduction}

During the Soviet occupation of 1945-1991, Estonia became a Soviet Republic. The four decades of totalitarian occupation, brought serious damage to both, to the state and people of Estonia. A large proportion of the pre-war population was either killed, deported to Russia (mass deportations to Siberia in 1941 and 1949) or escaped to the West - the percentage of Estonians also dropped significantly as the Soviet Union started the process of russification during which hundreds of thousands of

\footnotetext{
${ }^{1}$ Corresponding author: annleena.miller@student.emu.ee
} 
Russians were settled in Estonia. Industry was set as a priority throughout the Soviet period. The pre-war economy, based mainly on agriculture and single-family farms, was destroyed as the owners of the wealthier farms were deported to Siberia and the land was forcefully nationalised (1944-47). The agricultural landscape pattern changed even more due to the state-driven policy of collectivisation and altogether the traditional rural lifestyle was ruined as the existing farms were reorganized in the state farms (sovhozes) and collective farms (kolkhozes). With the beginning of urbanisation (1950s), many moved from one-family farms to the new kolkhoz and sovhoz centres to live in the modern concrete-panelled khrushchevkas - the architectural landmarks of the period.

The development of modernist rural landscapes in Estonia was mostly influenced by nationalisation and collectivisation - however, there was another process that changed the landscape pattern significantly - militarization. As the Estonian coastline $(1242 \mathrm{~km}$ of mainland coastline and $2552 \mathrm{~km}$ of insular coastline) [1] was now the outer border of the Soviet Union and part of the Iron Curtain, Estonia was cut off from open contact with the Western world. Historically the Estonian coastline was neither heavily populated nor a recreational area for the wealthy elites and the main economic activity was focused on trading ports and local fishing industries [2]. However, during the Soviet occupation free access to the sea was abruptly ceased for security reasons - the coastline and mainland to a distance of twenty kilometres from the coast together with the insular became exclusion security zones [3].

From 1944-1990 three conceptual categories of restrictions existed: the north coast (Zone I), the open sea coasts of the Western Estonian Archipelago (Zone II) and the West Coast (Zone III) [4]. It is estimated that altogether $14-25 \%$ of Estonian territory was under direct military control for security reasons [5], this includes towns with sensitive military, scientific or industrial facilities, coastal areas and islands that were now accessible only with special permits [3]. Large-scale depopulation took place in military controlled areas and only three types of activities were allowed: fishing kolkhoz (rybkhoz), mineral extraction and military presence [3]. Local authorities surrounded all ports in border zones with security fences and conducted continuous surveillance around these fences [3] and access to coastal areas was restricted. The traditional activities of local inhabitants were limited or prohibited altogether and as a result, the traditional coastal settlements started disappearing together with the original rural landscapes [3]. Instead, a distinctive military landscape began to emerge alongside collectivised agriculture, where residential quarters, roads and communications formed unique complexes.

\section{The development of a military landscape}

The occupation period added a military layer to the landscape, containing military installations like observation posts, missile bases, coastal defence batteries, trenches, observation towers, barracks, bunkers, border-guard stations, airfields, radar stations, commando points and army campuses, etc. Building military structures and monuments has always been a significant way for foreign rulers to show their power and mark their territory [6]. Estonia did not have armed forces of its own, but because of the strategic geographical location as a borderland between the East and the West, a substantial part of the Soviet military was present on the territory of Estonia in the form of Soviet Red Army and Air Force, but the exact number of military units in Estonia is unknown. On the coast of the Baltic Sea militarization was maybe less visible than in some places (e.g. the Berlin wall), but the military control was no less restrictive [3] (fig. 1). The military presence was mostly concentrated at the northern coast and on the western islands of 
Estonia - the coastal border zone, where observation posts and towers were built at regular intervals [3] and the towns of Paldiski (Soviet Nuclear Training Centre) and Sillamäe (Uranium Enrichment Factory - Kombinat 7). The remainder of the territorial area of Estonia was unrestricted, except in the environs of military bases and other (civilian) restricted areas [3]. Nevertheless, the country was heavily militarized, with closed military areas covering almost $2 \%$ of Estonian territory [7]. There was a massive construction programme of artillery defensive positions along the coastline [8]. Most modern military structures were established outside towns and constructed for a short period of use, also usable installations built in previous decades and by previous rulers (German, tsarist Russian) were reused by the Soviets. It was characteristic to the military building system to use scrap bricks, low cost labour (military construction battalions), mass production and weak control of materials [8]. Because of the military presence and prohibited access, entire regions and whole towns disappeared from the map as well as from the mind of the nation for decades.

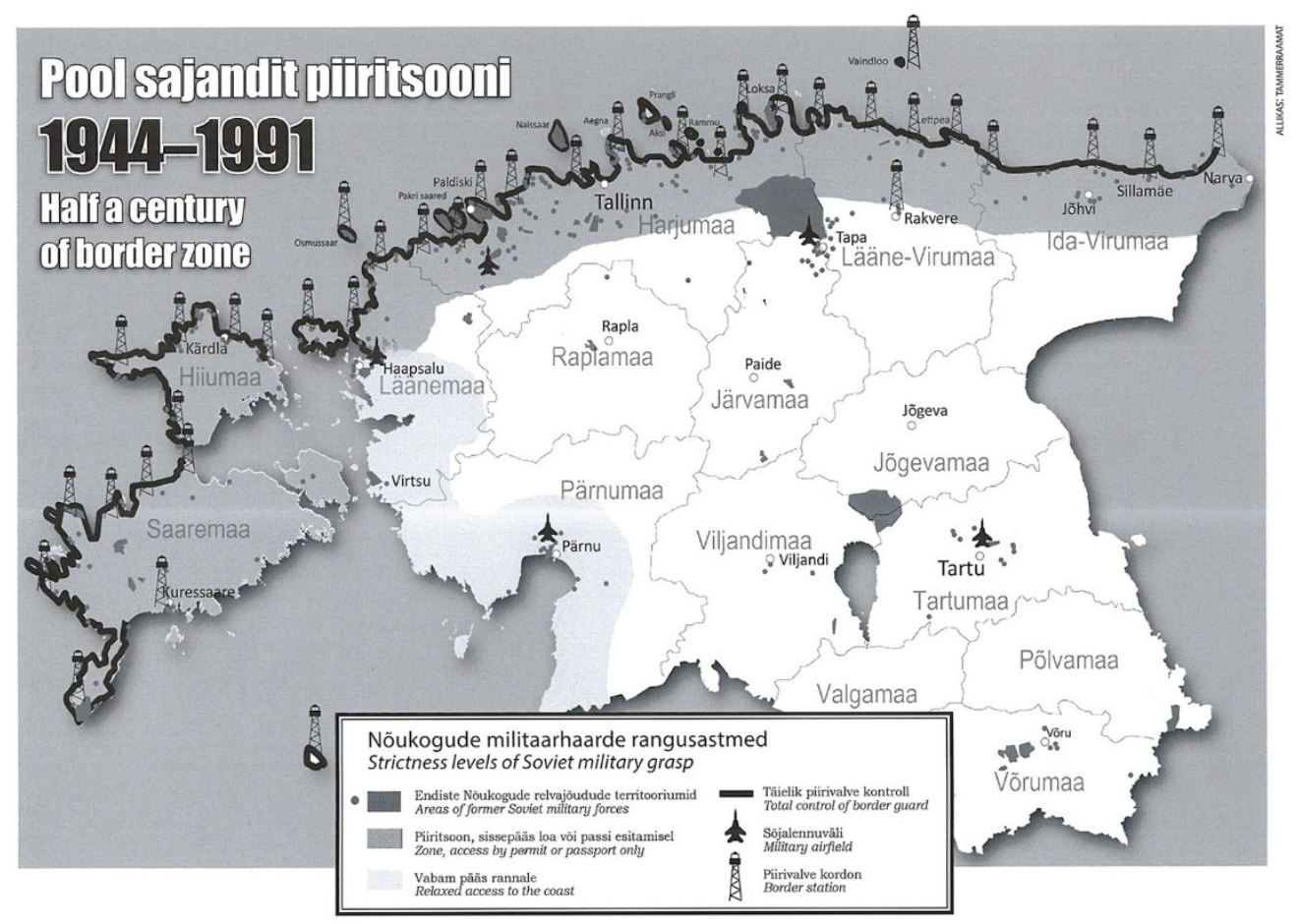

Fig. 1. The restricted areas during the Soviet occupation. (Source: [5]).

Today Soviet military heritage is not under protection (except 63 objects in Hiiumaa). The actual extent of the legacy left behind the Soviet military in 1994, when the last troops left Estonia, is enormous. The exact number of Soviet military objects in Estonia is not known: Raukas [7] mentions 1565 objects at 800 sites ( 87147 ha) which is approximately $1,9 \%$ of the territory of Estonia; the statistics of the Russian authorities mention the presence 4900 military objects in Estonia and the Estonian Ministry of Defence refers to 1581 objects [3]. Most of the military installations were stripped of anything useful by the Soviets so they could not be used for the same purpose anymore. Employing Soviet military structures for civilian use was technically nearly impossible because of the poor building quality and the fact that most of them were located in the periphery with no usable infrastructures which made the costs of re-use too high. With the Land Reform of 1991 the nationalised land was returned to its former owners, so many military objects became 
private property. There was also the problem of pollution: Raukas [9] has reported that the Soviet military had polluted extensive areas of soil with oil fuel products (4335 ha), scrap metal ( $850 \mathrm{ha}$ ) and chemicals ( $85 \mathrm{ha}$ ). Any economic benefits of displaying such landmarks as tourist attractions were diminished by their sheer extent and uniformity, as well as by their potential to evoke painful memories in the newly independent nation [10]. As there were no resources and no State interest, most of the structures were ignored and forgotten for decades. They were left open to the elements and slowly began to deteriorate leaving the sites to become derelict wastelands (fig. 2). Altogether, the existence of the border-zone caused a paradoxical combination of vast areas of land contaminated by toxic waste and derelict buildings but also vast natural areas rich in biodiversity to develop and to be preserved [2] (fig. 3).

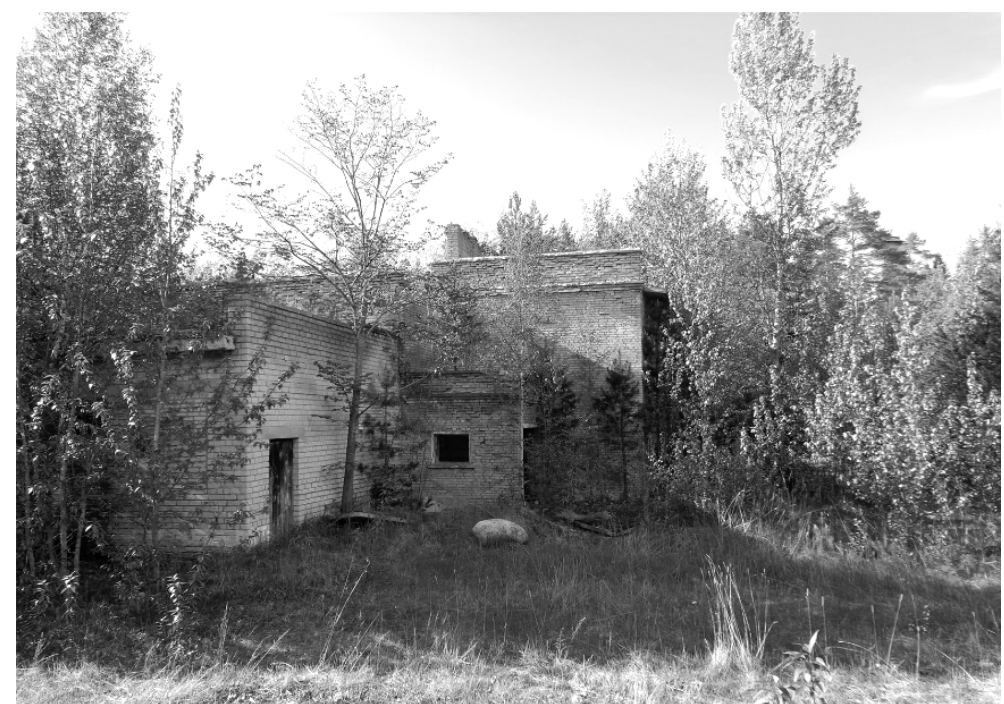

Fig. 2. Most of the Soviet military installations are abandoned and taken over by the nature (Soviet military remnants in Suurpea).

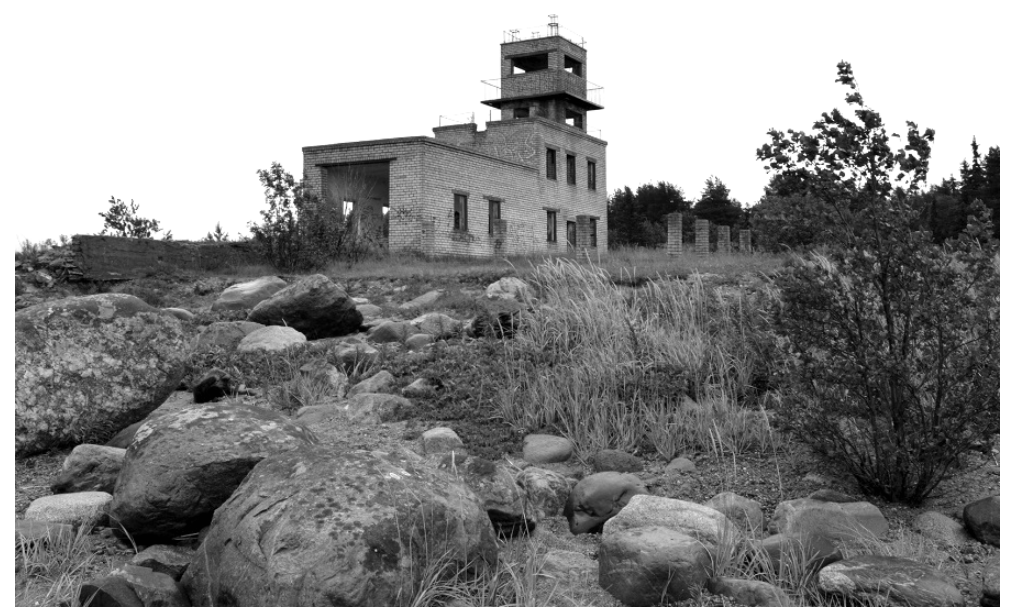

Fig. 3. The former border guard building in Pärispea is located in the Estonian Green Belt area in Lahemaa National park. 


\section{Aims and methods}

History becomes heritage only when defined in the context of landscape and interpreted through collective memory [11]. This article concentrates on revealing how the Soviet border-zone and the extent of restrictions were physically as well as mentally ever present in the lives of the local people during the occupation period and whether and how it has changed the attitude towards the Soviet military legacy that is still physically existing in the cultural landscape of the present day. A section of the NE coast of Estonia (including Sillamäe) was chosen as case study area for in depth analysis. Using the data available from the mapping of the military objects of Estonian Green Belt [12] and the database of heritage culture objects [13] combined with on-site visits to the Soviet military sites, assessment of their condition and their visible presence - a distinctive military landscape was revealed. Knowing that, a qualitative research was carried out using face-to-face interviews with local residents to understand the influence of that military layer to the local people and their identity.

The interviews were built up as semi-structured as it gave the interviewer a chance to ask a set of predetermined and standardised questions along with more spontaneous questions to highlight and clarify certain issues. The interviews were recorded and detailed notes were made. Altogether 49 interviews (ongoing process) were conducted with people from different age groups living in the case study area. The standardised part of the questions was divided into two categories: 1) personal experiences connected to the restricted military areas during the period of Soviet occupation; 2) the interest in Soviet military legacy today and its role in Estonian heritage. In cases, where the interviewed person was born after the Soviet occupation and could not have any personal memory of the time, the first block of questions was replaced with questions about their knowledge of the restricted Soviet military areas and their sources of information on that topic to see if they are influenced by prejudice in their answers.

\section{Results}

The results reveal that most of the interviewees had had some kind of personal experiences with military restrictions during the Soviet period. First, the border zone prohibited people from moving freely. The majority had visited the border zone areas with an invitation or lived in restricted the area; there were also some interviewees who had a work-related permit to visit the closed and military controlled town of Sillamäe. People living inside the restricted border zone, had a permit in their passport and could therefore move almost freely between the restricted area and the non-restricted hinterland, but always had to have their passports with them when crossing the zone border. Most of the interviewees, although living close to the border zone, did not have a border-zone permit and instead used an invitation from family of friends to apply for a permit for entering restricted area, which could take up to a month to get, or visited the areas secretly. This meant that every trip had to be pre-planned and there was a lot of bureaucracy, as everything had to be documented. Another thing with the permit system was that when the younger generation, who had lived in the restricted zone previously, went to school elsewhere, they had to register themselves to the place they went to school to and write themselves out of their parents' house. This meant that they lost their permit and had to get an invitation and fill in the same paperwork as the guests to visit their home and could not move freely anymore.

There were also restrictions inside the border-zone, for example people were not allowed to go swimming at every beach; there were certain times of the day where it 
was prohibited to go to the beach even for a walk in some places; some beaches were raked and fenced with barbed wire (fig. 4) to make sure no one went close to the water. People still went to the beach secretly, even if they had to take their own rake with them to erase their footprints afterwards. Even then most of the interviewees rated the direct impact of the restrictions on their everyday life as low when being inside or outside of the restricted area, but still unpleasant and annoying. People were mostly afraid of confronting the military personnel or the border guard when crossing the border of the restricted zone or when trespassing. The majority of the military personnel and the border guard was Russian and neither understood nor spoke Estonian, which could sometimes cause problems and misunderstandings. There were also a lot of descriptions of the border guards going to local parties, dancing with local girls and trying to blend in, but to keep the border guard personnel from getting too attached with the locals and focused on their work, they were rotated to different locations every once in a while. There was also at least one armed conflict (the border guard always carried guns) at a local party that several respondents referred to, where the border guards were drunk and opened fire. Some of the older respondents also had memories of men in uniform coming to their farms when they were kids, carrying guns and talking in Russian, asking about their parents or taking all the food they could find with them.

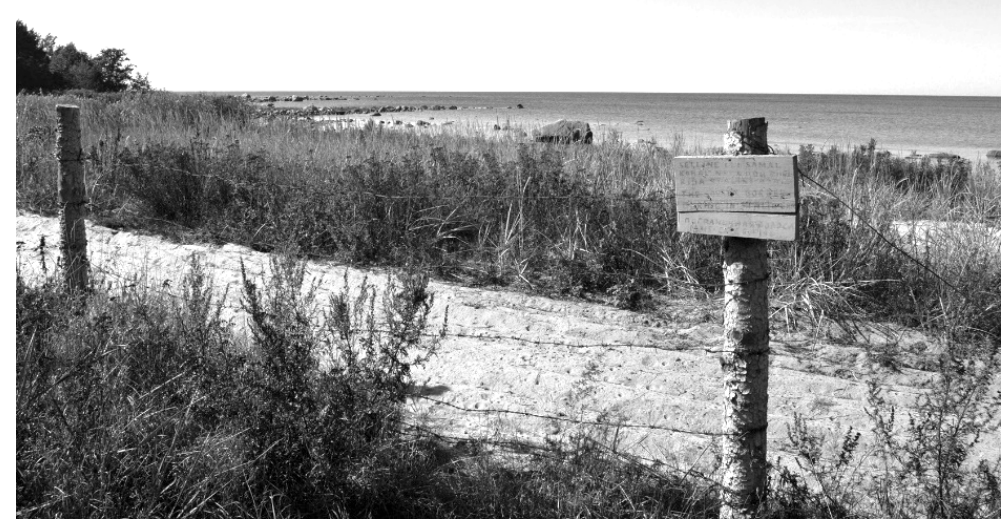

Fig. 4. The reminder of the raked and fenced beach security zone in Juminda.

The former resort village of Sillamäe (fig. 5) was turned into a closed military town in 1940s, when the old oil shale processing plant was rebuilt for uranium production using the labour of convicts and war prisoners [14]. The town was closed for outsiders without special permits and inhabited by military personnel and scientists who were nearly all Russian speakers brought from other parts of the Soviet Union. Nevertheless, the town was famous as a trade centre. Most of the respondents from Ida-Virumaa said that they had visited the town secretly at some point to buy things you could not find in regular shops elsewhere. Although the town was heavily militarized, it was not that hard to get in, if you knew where and when to enter. However, it was a lot harder to move around unnoticed, as you could be exposed in any shop because of an Estonian accent or asked to show your passport to check the permit, which is why all the respondents said that they felt the military presence there 
and were alert at all times. It was said that the town itself was beautiful, but they visited it mostly for mercantile interest and not for fun or vacation.

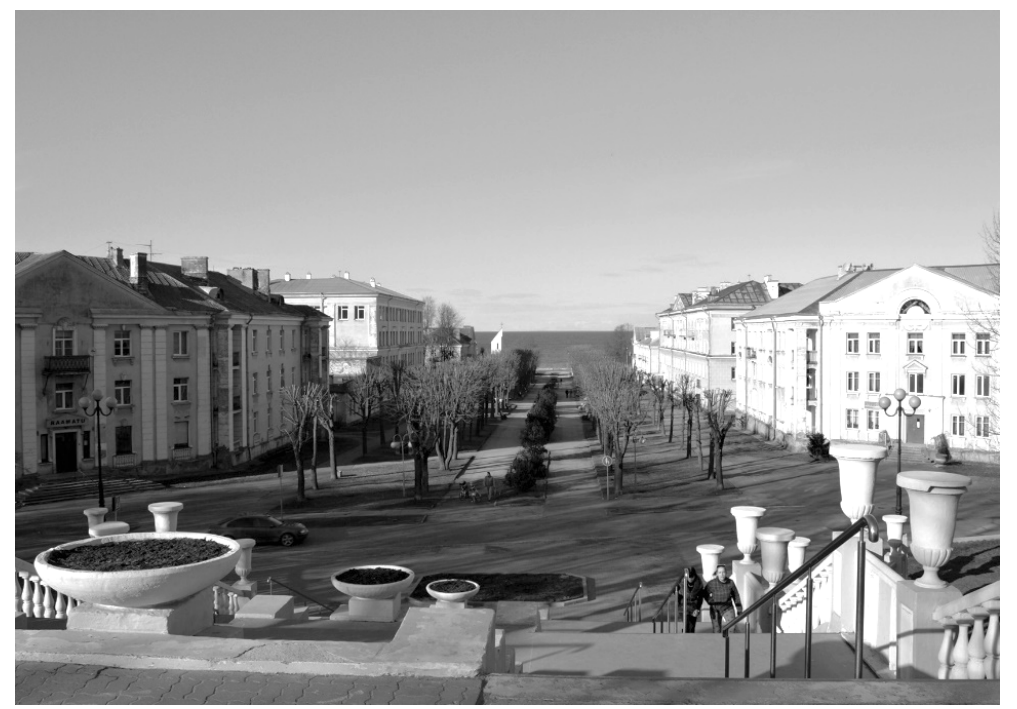

Fig. 5. The former closed military town of Sillamäe.

All interviewees had visited Soviet military installations after the occupation period. The visits were mostly random (the installations were seen from the road), because people did not exactly know the locations of the objects, and with family or friends. There were some who wanted to show the installations as local curiosities to their visitors and some who liked visiting abandon places as a hobby. When asked about the military feeling in the abandoned sites, most of the respondents rated it as low. It was highlighted that instead of feeling a military presence they felt uncomfortable as the installations were dangerous because of their poor condition. It was mentioned several times that while visiting the sites it was unclear whether they were allowed to go there or not as there were no signs and no information about the sites.

When assessing the visual aesthetics of the buildings, they were mostly rated by the interviewees as ugly, boring, without an architectural value and not fitting the landscape although their surroundings were seen as beautiful natural sites. None of the interviewees thought that Soviet military heritage should be taken under protection or preserved for future generations. However, there were some, who said that some of the objects that are more interesting (fig. 6), in better condition and could be easily located, should be renovated and a new use should be found for these. There was the beginning of interest in visiting such sites in all age groups, but the younger ones with no occupation time experiences were more eager to get to know more about such sites. The older interviewees said that although the Soviets are gone, they still feel unpleasant around such sites, but would visit them when safe and correctly guided (signs, information boards, etc.). 


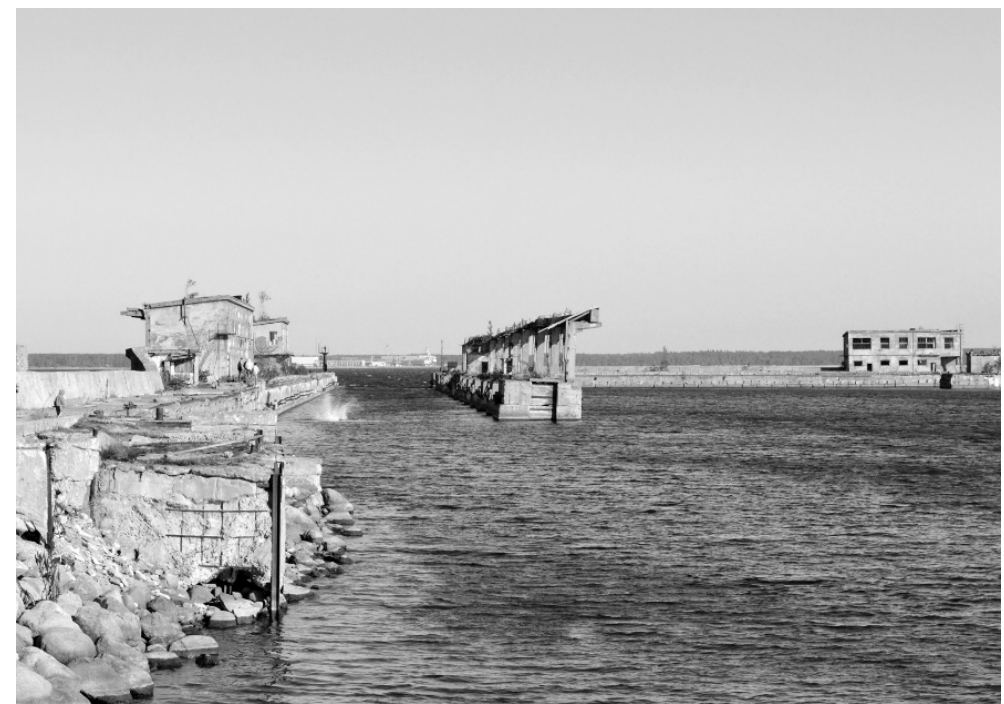

Fig. 6. The former Soviet Submarine Demagnetising Base in Hara is mostly seen as unique and a site worth preserving.

The interviewees without personal memory of the Soviet period had heard of the border zone and closed military towns either from their parents, books, TV or history teachers, but the information was very general, a little confused and they mostly could not connect it to certain areas or name any restrictions. The overall attitude in that age group was indifferent as they had no personal experiences.

\section{Discussion}

The past is valued and understood differently by different individuals - heritage is created through interpretation and not just what is interpreted, but by whom it is done and how [15]. Soviet military legacy is not an obvious choice for discussing Estonian heritage as it is seen as the 'non-Estonian' and unwanted past of the country [10]. It is defined as dissonant heritage with conflicting meanings and opposing uses representing the disharmonies, conflicts and general lack of agreement between the past and present use of sites with conflicting history [15] and it makes us feel discomfort [16]. It is interesting that when asked about the Soviet period, most interviewees started with positive memories - this shows that enough time has passed so that people are starting to feel nostalgia rather than fear. Yes, the restrictions were there, the fear and dislike against the occupation as well and when given a little time to think, people also remembered negative experiences, but they talked about them as curious and not horror stories. What was interesting is that people of the so-called Soviet generations changed their opinion about the Soviet occupation and the restrictions several times during the interviews - it varied from positive to negative. The negative attitude against the Soviet remnants today was more influenced by the fact that most of the installations are physically in dangerous condition rather than by the connection to the Soviet ideology - meaning that the objects were valued in the present and not in the past.

Older generations with pre-occupation experiences were more prejudiced than their children, who had born during the occupation time and therefore did not know what the life had been like before the restrictions - it was their everyday. The youth of today, however had no personal experiences with the Soviet occupation at all and were therefore 
mostly indifferent about the Soviet heritage. History shows that foreign elements and people can be accepted as part of the national heritage when enough time has passed and they no longer pose a direct threat [10] - as time passes by the negative experience is then seen and evaluated from distance and generations change, the negative experience becomes more impersonal. Over time, old standpoints are reviewed and reconsidered, so maybe the objects we do not consider as heritage today, may be regarded as deserving protection tomorrow [17]. "The past can never be understood solely within its own terms; the present continually rewrites the meaning of the past and the memories and histories we construct about it within the context of the present" [16: 58].

\section{Conclusions}

All in all, the Soviet military legacy is seen as a part of Estonian cultural landscape and heritage despite its history of foreign occupation, although it was also said, that such sites are still an unpleasant physical memory of the period and should rather be left alone. The dissonant character of it is still problematic, but is seems that Soviet remnants are in general starting to be valued as more dissonant or neutral and less as negative today. A number of Estonian cultural landmarks (castles, manor houses, churches) are actually of foreign origin [10] and were once seen as hated landmarks built by foreign rulers. Of course, Soviet remnants symbolize a period of occupation, restricted access and even acts of repression, but as time has passed the collective memory has started to change. So, today there might be the question of whether or not a Baltic-German manor house is more Estonian heritage than the Soviet military installations? Yes, would be the obvious answer today, but maybe not for future generations.

As part of the landscape the military objects and territories were developed separate from the collectivisation but there were clear interrelationships and similar processes land abandonment, re-naturing of former agricultural land grown to forest as seen in the reorganisation of the farms. Military modernisation was of course a constant feature of the landscape and this heritage layer can be read together with the rest of the Sovietera modernisation programme - if you know where to look.

\section{Brief Resume}

Ann-Leena Miller is a landscape architect with a master degree from the Estonian University of life Sciences. She is gradually carrying out a PhD project on the Soviet military landscapes of Estonia

\section{References}

1. RAUKAS, A. (ed.) 1995. Estonian Nature, Tallinn, Estonian Encyclopaedia Publisher.

2. VOLLMER, E.; SEPP, K.; RAET, J. 2010. Estonian Green Belt: Values and Management Issues, Estonia, Estonian University Life Sciences.

3. SEPP, K (ed.) 2011. The Estonian Green Belt, Tallinn, Estonian University of Life Sciences. Retrieved from: http://citeseerx.ist.psu.edu/viewdoc/download?doi=10.1.1.465.5277\&rep=rep1\&ty pe $=$ pdf [available on 11 March 2019].

4. PÄRN, J.; PEEPSON, A, 2011, "Restricted access border zones of the Estonian Soviet Socialist Republic", in K. Sepp (ed.), Op. cit. [3]: 12-15. 
5. KUUSK, K.; KÄRGINEN, M. 2013. Stopp! Piiritsoon / Stop! Border zone, Tallinn, Tallinna Raamatutrükikoda.

6. TREUFELDT, R. 2013. Sõjaline pärand [Military heritage]. Web page. Kultuuripärandi aasta 2013 [The Year of Cultural Heritage 2013]. Retrieved from: http://www.parandiaasta.ee/kultuuriparand/sojaline-parand (available on 10 May 2017].

7. RAUKAS, A. 1999. Endise Nõukogude Liidu sõjaväe jääkreostus ja selle likvideerimine [Residual pollution of the former Soviet Union and its elimination], Tallinn, Eesti Vabariigi Keskkonnaministeerium [Ministry of the Environment of the Republic of Estonia]. Retrieved from: http://www.digar.ee/id/nlib-digar:11816 [available on 11 March 2019].

8. PÄRN, J., 2011, "Soviet military infrastructure and its formation in Estonia", in K. Sepp (ed.), Op. cit. [3]: 15-32.

9. RAUKAS, A. (ed.) 2006, Nõukogude okupatsiooni poolt tekitatud keskkonnakahjud [Environmental damage caused by the Soviet occupation], Tallinn, Estonian Encyclopaedia Publisher.

10. PEIL, T. 2005, "Estonian heritage connections - people, past and place: the Pakri Peninsula", International Journal of Heritage Studies, vol. 11, $\mathrm{n}^{\circ}$ 1: 53-65.

DOI: https://doi.org/10.1080/13527250500037021

11. SOOVÄLI-SEPPING, H. 2014. "Kedagi pole unustatud, midagi ei unustata" [No one is forgotten, nothing is forgotten], in L. Kaljundi; H. Sooväli-Sepping (eds.), Maastik ja mälu: pärandiloome arengujooni Eestis [Landscape and memory: development of heritage in Estonia], Tallinn, Tallinna Ülikooli Kirjastus: 349-364.

12. Maps of military objects in the Estonian Green Belt rom the Estonian Green Belt project (2011). Web page [in Estonian]. Estonian University of Life Sciences, Institute of Agricultural and Environmental Sciences, Chair of Environmental Protection and Landscape Management. Retrieved from:

http://pk.emu.ee/struktuur/keskkonnakaitsejamaastikukorraldus/projektid/balticgre enbelt/militaarobjektid/ [available on 10 February 2018].

13. Maps of cultural heritage objects (2018). Online interactive map and database. Estonian Nature Information System (EELIS). Retrieved from: http://loodus. keskkonnainfo.ee/eelis/default.aspx ?id=449252827\&state $=2 ; 152503$ 6761; eng; eelisand;; [available on 10 February 2018].

14. RASMUSSEN, J. B. 2010. Travel Guide: Traces of the Cold War Period: The Countries Around the Baltic Sea, Copenhagen, Nordic Council of Ministers. Retrieved from: http://coldwarsites.net/wpcontent/uploads/2017/12/travel_giude_www39.pdf [available on 11 March 2019].

15. TUNBRIDGE, J. E.; ASHWORTH, G. J. 1996. Dissonant heritage: The management of the Past as a Resource in Conflict, Chichester, John Wiley \& Sons.

16. SMITH, L. 2006. Uses of heritage, London, Routledge.

DOI: https://doi.org/10.4324/9780203602263

17. TARANG, L., Pärandkultuuri mõistest ja pärandkultuuri jäädvustamisest [The concept of and recording of cultural heritage]. Web page. RMK (Riigimetsa Majandamise Keskus - State Forest Management Centre. Retrieved from: https://www.rmk.ee/metsa-

majandamine/parandkultuur/lisalugemist/parandkultuuri-moistest-jajaadvustamisest [available on 10 February 2018]. 